J. Clin. Chem. Clin. Biochem.

Vol. 18, 1980, pp. 293-295

\title{
Determination of Orotic Acid in Children's Urine
}

\author{
By C. Bachmann and J. P. Colombo
}

Chemisches Zentrallabor der Universitätskliniken, Inselspital, CH-3010 Bern

(Received July 24, 1979/January 21, 1980)

Summary: A reliable method is described for the determination of urinary orotic acid. The orotic acid is separated quickly and easily from the urine by anion exchange chromatography. Reference values are reported for children. The method is suitable for the differentiation of those inherited metabolic defects that lead to hyperammonemia.

\section{Bestimmung der Orotsäure im Urin bei Kindern}

Zusammenfassung: Wir beschreiben eine zuverlässige Methode zur Bestimmung der Orotsäure im Urin. Die Auftrennung durch Anionenaustauschchromatographie benötigt einen minimen Arbeitsaufwand. Referenzwerte für Kinder werden angegeben. Die Methode eignet sich zur Differenzierung von erblichen Stoffwechseldefekten, welche zur Hyperammonämie führen.

\section{Introduction}

Orotic acid is an intermediate in pyrimidine synthesis. An increase in the urinary excretion of orotic acid is found in primary orotic aciduria (1) and in inborn errors of urea synthesis (2). Its determination in urine is useful in the differential diagnosis of hyperammonemia in children. We describe an anion exchange chromatographic method which is rapid, simple and reliable, and suitable for low concentrations of orotic acid.

\section{Materials and Methods}

Orotic acid monohydrate was obtained from Sigma (St. Louis). Animex A-25 (chloride form, particle size $17.5 \mu \mathrm{m}$, BIORAD, Richmond), converted to the formate form, was used in a $0.5 \times 18 \mathrm{~cm}$ glass column (HGT-Säule, Serva-Technik, Heidelberg). Aqueous formic acid (Merck p. a.), $4 \mathrm{~mol} / \mathrm{l}$, was used as eluent. It was degassed under vacuum prior to use. The eluent was pumped through the column at a rate of $0.84 \mathrm{ml} / \mathrm{min}$ and a pressure of $690 \mathrm{kPa}$ with a positive displacement pump (Milton Roy). The absorbance of the eluent was continuously monitored in a $200 \mu \mathrm{l}$ flow cell (Hellma, Mullheim, $d=1 \mathrm{~cm}$ ) with a spectrophotometer set at $280 \mathrm{~nm}$ (LC 55, Perkin Elmer) and registered with a recorder at $0.04-0.2$ absorbance full scale. The peak height was used for calculating concentrations.

The urine samples were adjusted to $\mathrm{pH} 7-8$ with $\mathrm{NaOH}$ $(6 \mathrm{~mol} / \mathrm{l})$, mixed, and centrifuged at $2000 \mathrm{~g} .0 .50 \mathrm{ml}$ of the supernatant was applied to the column with the aid of a sample loop.

Creatinine was determined by a modified Jaffe reaction on the Greiner selective analyser (GSA II) (3). Urine samples for reference values were obtained from healthy neonates, from healthy children in a day care conter, and from hospitalised children suffering from nonmetabolic diseases including febrile conditions.
Recovery experiments were done by determination of orotic acid in urines spiked with four different concentrations of orotic acid. Daily determinations of each of these urines were performed over six days. The day to day precision was calculated from these replicates. The intraseries precision was calculated from a patient's sample analysed serially ten times.

\section{Results}

Orotic acid elutes at $57 \mathrm{ml}$, (orotidine at $33.2 \mathrm{ml}$ ). The recovery of different concentrations of orotic acid added to urine containing no measurable orotic acid are shown in table 1. Data on the day to day precision are also included. The coefficient of variation of 10 replicates of a patient's urine containing $104 \mu \mathrm{mol} / 1$ of orotic acid, analysed in a series was $1.95 \%$. The method is linear from 2 up to at least $250 \mu \mathrm{mol} / \mathrm{l}$. Technician time for one determination is less than ten minutes.

Figure 1 shows the chromatogram of a normal urine with that of a patient with ornithine transcarbamylase (EC 2.1.3.3.) deficiency superimposed. No interfering substances have been found so far in the urines of patients with a variety of disorders including tyrosinemia and Lesch-Nyhan-Syndrome. Reference values for children are shown in table 2 . We only give median values and ranges since the analysis of distribution of the population is not symmetric. It appears that hospitalized children with no disease leading to hyperammonemia have a slightly higher orotic acid excretion than healthy children, but still much less than patients with congenital disorders of the urea cycle. 
Tab. 1. Recovery of orotic acid added to urine and day to day precision.

\begin{tabular}{lcll}
\hline $\begin{array}{l}\text { Orotic acid, final concentration } \\
\text { calculated } \\
\text { measured }\end{array}$ & Recovery & $\begin{array}{l}\text { Precision } \\
\text { (CV, day } \\
\text { to day } \\
(\mathrm{n}=6))\end{array}$ \\
$(\mu \mathrm{mol} / 1$ & $(\mu \mathrm{mol} / \mathrm{l})$ & $(\%)$ & $(\%)$ \\
\hline 4 & 3.6 & 89.3 & 17.7 \\
16 & 14.6 & 91.1 & 10.5 \\
64 & 60.6 & 94.7 & 5.2 \\
128 & 122.1 & 95.4 & 3.9 \\
\hline
\end{tabular}

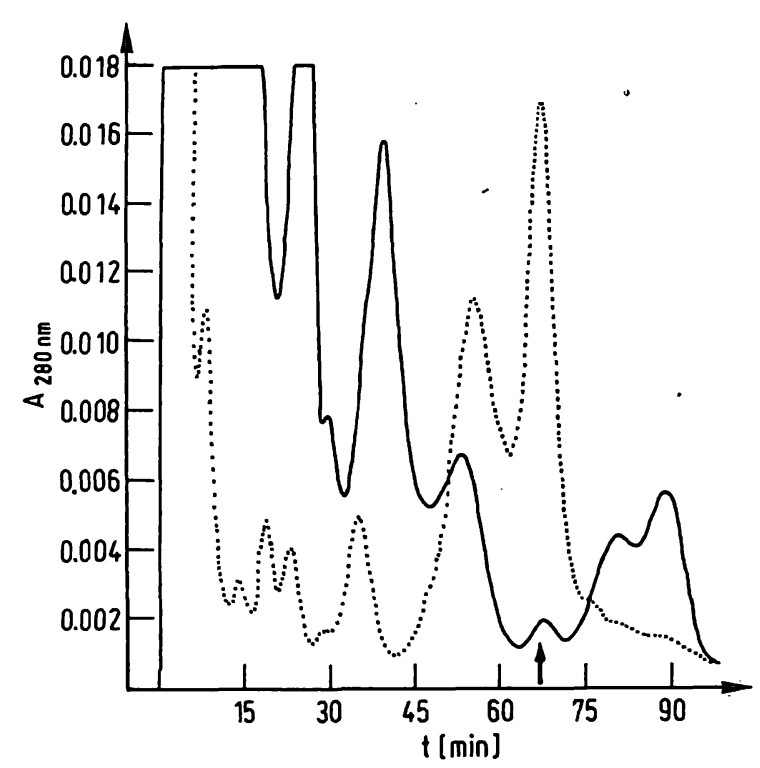

Fig. 1. Chromatogram of a urine of a normal child (-), and of the urine (diluted 1:10) of a patient with ornithine transcarbamylase deficiency $(\cdots \cdots \cdot . \cdot)$. The arrow indicates the orotic acid peak.

Tab. 2. Reference values (children).

\begin{tabular}{|c|c|c|c|c|}
\hline & $\begin{array}{l}\text { Orotic ac } \\
\text { ( } \mu \mathrm{mol} / 1) \\
\text { Median }\end{array}$ & $\begin{array}{l}\text { cid } \\
\text { Range }\end{array}$ & $\begin{array}{l}(\mu \mathrm{mol} / \mathrm{g} \\
\text { Median }\end{array}$ & $\begin{array}{l}\text { creatinine) } \\
\text { Range }\end{array}$ \\
\hline Newborns $(n=8)$ & 2.1 & $0.73-8.0$ & 12.1 & $\begin{array}{ll}6 & -29\end{array}$ \\
\hline \multicolumn{5}{|l|}{$\begin{array}{l}\text { Hospitalized } \\
\text { children: }\end{array}$} \\
\hline $\begin{array}{l}1 \text { month }-1 \text { year } \\
(n=12)\end{array}$ & 1.6 & $0.44-7.8$ & 5.4 & $1.7-34$ \\
\hline $\begin{array}{l}1 \text { year }-7 \text { years } \\
(n=8)\end{array}$ & 1.8 & $0.45-6.4$ & 2.2 & $0.7-3.9$ \\
\hline \multicolumn{5}{|l|}{$\begin{array}{l}\text { Healthy children } \\
(n=22)\end{array}$} \\
\hline 2-14. years & trace & trace -1.5 & trace & trace -1.7 \\
\hline
\end{tabular}

\section{Discussion}

The present method is reliable, rapid, more sensitive and less cumbersome than the colorimetric procedure of Adachi et al. (4). Interference with the colorimetric method by various substances has been discussed by Kesner (5), who described a separation on silicic acid. Our method involves less working time than the latter. Animex A-25 gives a better separation of the urinary compounds absorbing at $280 \mathrm{~nm}$ than Dowex I (6). It is also more sensitive.

Although more rapid chromatographic systems have been described involving high pressure liquid chromatography (7), their practicability is hampered by time consuming sample preparation.

The method described herein has proved its usefulness during the last five years for the noninvasive diagnosis of ornithine transcarbamylase deficiency, delineating this disorder from other causes of hyperammonemia. Patients with ornithine transcarbamylase deficiency exhibit a nonspecific amino acid pattern in plasma and urine, whereas citrullinemia, argininosuccinic aciduria and argininemia can be diagnosed by the amino acid chromatography. The unspecific amino acid pattern of ornithine transcarbamylase deficiency cannot be differentiated from that found in several other disorders leading to hyperammonemia, like carbamyl phosphate synthetase deficiency or organic acidurias (propionic acidemia, methylmalonic acidemia, disorders of biotin metabolism). These conditions do not lead in our experience to orotic acid elevation. In ornithine transcarbamylase deficiency, however, orotate is markedly increased (96-9220 $\mu \mathrm{mol} / \mathrm{g}$ creatinine in 13 patients), well above the upper limit of our reference sample of hospitalized patients. We consider that these patients, and not the group of healthy children, represent an adequate reference population; this is because the samples of patients with hyperammonemia are mostly obtained during episodes in which the children are critically ill and in a catabolic state. This situation precipitates the disease and leads to hospitalisation.

\section{Acknowledgemẹnt}

We thank Mrs. Martine Hagen for her technical assistance. Supported by the Swiss National Science Foundation, grant nr. 3.591-75. 


\section{Referencès}

1. Kelley, W. N. \& Smith, L. H.: Hereditary orotic aciduria in: The metabolic basis of inherited disease (Stanbury, J. B., Wyngaarden, J. B. \& Fredrickson, D. S., eds.) McGraw Hill, New York 1978, p. 1045-1071.

2. Bachmann, C.: Urea Cycle in: Heritable disorders of aminoacid metabolism. (Nyhan, W. L., ed.). J. Wiley, New York 1974, p. $361-386$.

3. Colombo, J. P., Peheim, E. \& Flury, W.: Comparison of plasma creatinine determined with the Greiner Selective Analyzer GSA II and the glomerular filtration rate. Clin. Biochem. in press.
4. Adachi, T., Tanimura, A. \& Asahina, M. (1963), J. Vitaminol. 9, 217-226.

5. Kesner, L., Aronson, F. L., Silverman, M. \& Chan, P. C. (1975), Clin. Chem. 21, 353-355.

6. Bellinger, J. F. \& Buist, R. M. (1971), Clin. Chem. 17, 1132-33.

7. Naylor, E. W. \& Guthrie, R. (1979), J. Chromat. 163, 2936.

Dr. C. Bachmann

Chemisches Zentrallabor der Universitätskliniken Inselspital, 3010 Bern, Schweiz 
.

. 